\title{
PENGARUH PENGETAHUAN PRODUK, LABEL DAN PROMOSI TERHADAP KEPUTUSAN PEMBELIAN KOSMETIK HALAL DENGAN HARGA SEBAGAI MEDIASI
}

\author{
${ }^{1}$ Artantri Nugraheni, ${ }^{2}$ Sobrotul Imtikhanah dan ${ }^{3}$ Fadli Hudaya \\ ${ }^{1}$ Program Studi Ekonomi Syariah, FEB UMPP \\ ${ }^{2}$ Program Studi Akuntansi, FEB UMPP \\ ${ }^{3}$ Program Studi Ekonomi Syariah, FEB UMPP \\ mr.fadli82@gmail.com
}

\begin{abstract}
This study aimed to analyze the effect of Product Knowledge, Halal Label and Promotion on Purchasing Decisions of Halal Cosmetics Products with Price as a Mediation variable. The object in this study was a student at the Faculty of Economics and Business, University of Muhammadiyah Pekajangan Pekalongan. The sampling technique used was purposive sampling technique with a sample of 100 respondents. Primary data was collected through questionnaires using a Likert scale. The analysis technique in this study used path analysis with the mediation test using the Sobel test.

The results of this study indicated that: (1) Product Knowledge had a significant effect on Purchasing Decisions for Halal Cosmetics Products. (2) Halal Label had a significant effect on Purchasing Decisions for Halal Cosmetic Product. (3) Promotion had a significant effect on the Decisions to Purchase Halal Cosmetics Products. (4) Price can be a mediating variable between Product Knowledge, Halal Label and Promotion on Purchasing Decisions of Halal Cosmetics Products.
\end{abstract}

Keywords: Product Knowledge, Halal Label, Promotion, Purchasing Decisions and Price.

\section{PENDAHULUAN}

Manusia adalah makhluk hidup yang memiliki banyak kebutuhan dan keinginan dimana kebutuhan kebutuhan dan keinginan tiap individu pasti berbeda. Kebutuhan manusia merupakan suatu keadaan untuk memberikan kepuasan dasar yang dirasakan, suatu hal yang manusiawi apabila keinginan seorang wanita khususnya wanita dewasa untuk selalu tampil cantik dan menarik dimanapun dan kapanpun mereka berada (Rani dkk, 2014), oleh karena itu mereka akan menggunakan berbagai macam produk kecantikan guna menunjang penampilannya. Banyak cara yang dilakukan untuk mendapatkan penampilan yang diinginkan, salah satunya dengan memakai produk kosmetik.Penduduk Indonesia yang merupakan mayoritas beragama Islam tidak boleh meninggalkan kewajibannya sebagai seorang Muslim. Wanita muslim Indonesia memadukan gaya hidup yang modern dan Islami supaya 
tidak ketinggalan trend tanpa meninggalkan kewajiban sebagai muslim (Sari, 2019). Pengetahuan produk adalah pengetahuan yang diketahui konsumen mengenai manfaat produk, karakteristik, resiko untuk dikonsumsi dan kepuasaan setelah mengkonsumsi produk.

Berdasarkan penjelasan Director Consumer Market Insight 6Estates Rachel Zou terdapat dua faktor yang dapat mempengaruhi perubahan tren konsumsi dari produk luar negeri menjadi produk lokal. Faktor pertama, perempuan Indonesia mulai menyadari kecantikan etnis atau lokal dengan warna kulit yang beragam. Faktor kedua, adalah perempuan muslim saat ini lebih cerdas dan berhati-hati dalam pemilihan produk kecantikan dan skincare. Beberapa hal yang dimaksudkan terkait hal ini adalah bahan yang tidak mengandung alkohol, tidak mengandung bahan dari hewan dan label halal.

(https://lifestyle.bisnis.com/read/20190812/104/1135606/ini-penyebabkosmetik-indonesia-mulai-bersinar, diakses pada tanggal 3 Juni 2020)

Berdasarkan data dari databoks, konsumen Indonesia lebih memilih membeli produk kosmetik buatan luar negeri daripada produk lokal. Dengan hadirnya produk-produk kosmetik impor di Indonesia akan menyebabkan brand kosmetik Indonesia lesu akibat dari peredaran kosmetik global di Indonesia. Hal ini diakibatkan lingkungan Indonesia sudah dipengaruhi oleh global, produk kosmetik yang menjadi unggulan saat ini yaitu brand kosmetik dari China dan Korea karena kualitasnya yang sudah terjamin, walaupun dari segi harga untuk remaja tergolong mahal.

Gambar 1 Data Konsumen Kosmetik di Indonesia Tahun 2016

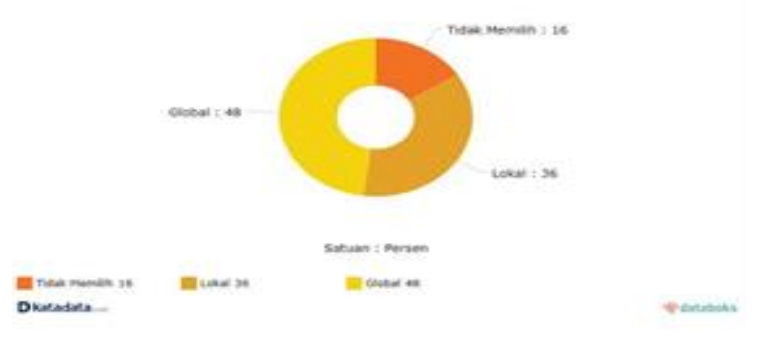

Dari gambar diatas menyimpulkan bahwa 48 persen konsumen menyukai kosmetik merek global, 36 persen memilih produk lokal dan 16 persen tidak memilih referensi apapun.

Di tengah tumbuhnya industri kosmetik saat ini, konsumen perlu waspada terhadap munculnya kosmetik ilegal yang dilarang BPOM beredar karena dapat membahayakan kulit. Dikutip kupang.tribunnews.com pada tahun 2018 BPOM RI telah menemukan 113 kosmetik yang dianggap berbahaya karena mengandung bahan yang dilarang atau bahan berbahaya.Terdapat beberapa produk kosmetik yang dipalsukan dengan harga asli produk tergolong mahal namun dapat dijual pasaran dengan harga lebih murah yang tentu menggunakan bahan tidak baik dan aman bagi kulit, walaupun sudah ditemukan namun masih banyak produk kosmetik yang beredar di pasaran mengandung bahan berbahaya dapat menjadi ancaman bagi kesehatan 
konsumen banyak konsumen online jadi korban kosmetik ilegal, konsumen dituntut untuk lebih teliti sebelum membeli produk kecantikan. Sebab, selain menghindari penipuan barang palsu, mengkhawatirkan mengandung bahan berbahaya. Terlebih saat ini marak modus pemalsuan produk kecantikan dengan merek ternama, produk tersebut dibuat hampir mirip dengan yang asli. BPPOM (Balai Besar Pengawasan obat dan Makanan) Mojokerto menemukan salah satu pemalsuan produk kosmetik atau kosmetik ilegal, semua produk tersebut merupakan hasil racikan tangan ibu rumah tangga dengan cara repacking.

(https://radarmojokerto.jawapos.com/read/2019/01/16/113970/bbpombanyak-konsumen-online-jadi-korban-kosmetik-ilegal, diakses pada tanggal 18 Juni 2020). Praktik pemalsuan kosmetik ini merupakan kejahatan yang akan merugikan berbagai pihak, diantaranya pemilik merek karena mereka tidak bersusah payah menciptakan sebuah merek produk kosmetik dan juga tidak mengeluarkan biaya yang banyak untuk membangun image melalui promosi atau iklan produk yang mereka repacking karena produk tersebut telah dikenal oleh masyarakat.

Bagi umat Muslim mengkonsumsi produk halal merupakan kewajiban. Halal artinya dibenarkan dan lawan dari halal adalah haram. Haram artinya sesuatu yang dilarang atau tidak dibenarkan menurut syariat Islam. Hukum mengenai kehalalan suatu hal mengacu pada Al Quran pada surat Al-Baqarah ayat 168:

"Hai sekalian manusia makanlah yang halal lagi baik dari apa yang terdapat di bumi, dan janganlah kamu mengikuti langkah-langkah syaitan;karena sesungguhnya syaitan itu adalah musuh yang nyata bagimu."(QS. 2:168) Labelisasi halal adalah label yang menginformasikan bahwa produk tersebut benar-benar halal dengan komposisi yang tidak mengandung unsur yang tidak diperbolehkan secara syariah. Halal diperuntukkan bagi segala sesuatu yang baik, bersih dan aman untuk dikonsumsi oleh manusia menurut syariat Islam. Dalam Islam, umat muslim diwajibkan untuk mengkonsumsi sesuatu yang halal karena sesuatu yang dikonsumsi akan mendarah daging dalam tubuh (Sadzalia, 2015). Produk yang berlabel halal akan lebih aman karena bahan baku yang digunakan jelas lebih aman. Oleh karena itu, kosmetik halal menjadi jawaban bagi para muslimah untuk tampil cantik namun tidak melanggar ajaran agama dengan menggunakan bahan yang halal.

Pada saat mempromosikan dagangan menggunakan sarana iklan yang menarik, baik dalam bentuk tulisan, lisan, maupun gambar. Tujuan dari promosi untuk memberitahu masyarakat agar mereka tahu dan kenal akan barang yang ditawarkan dan menjadi tertarik, media yang digunakan dalam promosi salah satunya yaitu media sosial. Manusia adalah makhluk sosial, karena itu manusia akan sering berkomunikasi kepada banyak orang. Dalam syariat Islam, hukum dalam promosi ada dalam fiqh dari pemahaman Al Quran dan Hadist sebagai sumber hukumnya. Dalam cara berpromosi, Islam dapat dijadikan sebagai pedoman untuk memberitahu cara mempromosikan yang sesuai dengan syariat Islam, Bahri (2013). Sebelum konsumen melakukan 
keputusan dalam pembelian terdapat beberapa faktor yang bisa mempengaruhi keputusan, salah satunya adalah harga. Harga akan memberikan penjelasan atau informasi kepada konsumen mengenai kualitas produk dan merk oleh produk tersebut. Jika harga dari produk di pasaran cukup tinggi ini berarti kualitas produk tersebut cukup baik, merk produk cukup bagus dan meyakinkan. Sebaliknya, apabila harga dari produk di pasaran rendah, maka bisa dikatakan bahwa kualitas produk tersebut kurang baik, merk produk kurang bagus, dan kurang meyakinkan bagi konsumen. Jadi harga bisa menjadi tolak ukur mengenai kualitas dan merk dari suatu produk. Berdasarkan uraian diatas, maka peneliti mengambil judul " PENGARUH PENGETAHUAN PRODUK, LABEL DAN PROMOSI TERHADAP KEPUTUSAN PEMBELIAN KOSMETIK HALAL DENGAN HARGA SEBAGAI MEDIASI".

\section{Rumusan Masalah}

Berdasarkan uraian latar belakang di atas, maka rumusan msaalah dalam penelitian ini adalah:

1. Bagaimana pengaruh pengetahuan produk mahasiswi Fakultas Ekonomika dan Bisnis Universitas Muhammadiyah Pekajangan Pekalongan terhadap produk kosmetik halal?

2. Bagaimana pengaruh label halal terhadap keputusan pembelian produk kosmetik halal?

3. Bagaimana pengaruh promosi terhadap keputusan pembelian produk kosmetik halal?

4. Apakah pengetahuan produk, label halal dan promosi berpengaruh signifikan terhadap keputusan pembelian produk kosmetik halal dengan harga sebagai variabel mediasi?

\section{Tujuan Penelitian}

Tujuan dari penelitian ini adalah:

1. Untuk menganalisis seberapa besar pengetahuan kosmetik berlabel halal pada mahasiswi Fakultas Ekonomika dan Bisnis Universitas Muhammadiyah Pekajangan Pekalongan.

2. Untuk mengetahui apakah label halal berpengaruh terhadap keputusan pembelian produk kosmetik halal.

3. Untuk mengetahui apakah promosi berpengaruh terhadap keputusan pembelian produk kosmetik halal.

4. Untuk mengetahui apakah pengetahuan produk, label halal dan promosi berpengaruh signifikan terhadap keputusan pembelian produk kosmetik halal dengan harga sebagai variabel mediasi.

\section{Kegunaan Penelitian}

Dari uraian pada perumusan masalah, maka kegunaan penelitian ini adalah:

1. Penelitian ini diharapkan mampu memberikan penjelasan mengenai pengaruh pengetahuan produk, label halal, dan promosi terhadap keputusan pembelian produk kosmetik halal. 
2. Mengetahui apakah variabel harga berpengaruh sebagai variabel mediasi dalam keputusan pembelian produk kosmetik halal.

3. Mampu menambah referensi di perpustakaan Fakultas Ekonomika dan Bisnis Universitas Muhammadiyah Pekajangan Pekalongan.

\section{TINJAUAN PUSTAKA}

\section{Theory of planned behavior}

Theory of Planned Behavior pertama kali dicetuskan oleh Ajzen pada tahun 1980 (Jogiyanto, 2007).Teori Perilaku Terencana atau TPB (Theory of Planned Behavior) merupakan pengembangan lebih lanjut dari Teori Perilaku Beralasan (Theory of Reasoned Action).TPB merupakan kerangka berpikir konseptual yang bertujuan untuk menjelaskan determinan perilaku tertentu.

\section{Perbedaan dengan Manajemen Konvensional}

Merupakan suatu sistem yang aplikasinya bersifat bebas nilai dan hanya berorientasi pada pencapaian manfaat duniawi semata.Manajemen konvensional ini berusaha diwarnai dengan nilai-nilai, namun perjalanannya tidak mampu. Sebab ia tidak bersumber dan berdasarkan petunjuk syariah yang bersifat sempurna, komprehensif dan sarat dengan kebenaran.

Negara Islam pada masa Rasulullah Saw, Khulafaur Rasyidin, Dinasti Umayyah dan Abasiyah telah menjalankan fungsi-fungsi manajemen; yaitu perencanaan (planning), pengorganisasian (organizing), pengarahan (actuating), dan pengawasan (controlling).

Manajemen dalam Islam bersandar pada ijtihad pemimpin dan umatnya, dengan catatan tidak boleh bertentangan dengan konsep dasar dan prinsip hukum yang bersumber dari Al-Quran dan Hadits.

\section{Kosmetik}

Kosmetik dikenal manusia sejak berabad-abad yang lalu.Pada abad ke-19 Hijriah, pemakaian kosmetik mulai mendapat perhatian, yaitu selain untuk kecantikan juga untuk kesehatan.Kosmetik menjadi salah satu bagian dunia usaha. Bahkan sekarang teknologi kosmetik begitu maju dan merupakan paduan antara kosmetik dan obat (pharmaceutical) atau yang disebut kosmetik medic (comeceuticals). (Tranggono dan Latifah, 2013: 3)

\section{Teori keputusan pembelian}

Proses pengambilan keputusan diawali oleh adanya kebutuhan yang berusaha untuk dipenuhi, pemenuhan kebutuhan ini terikat dengan beberapa alternatif sehingga perlu dilakukan evaluasi yang bertujuan untuk memperoleh alternatif terbaik dari persepsi konsumen, di dalam proses membandingkan ini konsumen memerlukan informasi yang jumlah dari tingkat kepentingannya tergantung kebutuhan konsumen serta situasi yang dihadapinya.

\section{Pengetahuan produk}

Konsep berwawasan produk berpendapat bahwa konsumen akan memilih produk yang menawarkan mutu, kinerja terbaik, atau hal-hal inovatif lainnya. Manajer dalam organisasi berwawasan produk 
memusatkan perhatian untuk membuat produk yang lebih baik dan terus menyempurnakan. Konsep berwawasan produk mengatakan bahwa konsumen akan menyukai produk yang menawarkan mutu, performansi dan ciri-ciri yang terbaik. Perusahaan yang menggunakan konsep berwawasan produk sering merancang produk mereka tanpa masukan dari pelanggan.Mereka percaya bahwa insinyur mereka tahu bagaimana merancang atau menyempurnakan produk, seringkali mereka bahkan tidak mempelajari produk pesaing karena barang-barang pesaing tidak dibuat disini (Sudaryono, 2016:54).

\section{Label Halal}

Label halal merupakan pernyataan halal pada kemasan produk untuk menunjukkan bahwa produk tersebut berstatus sebagai produk yang halal.Syarat kehalalan suatu produk diantaranya, tidak mengandung bahanbahan yang diharamkan seperti, bahan-bahan yang berasal dari organ manusia, darah, kotoran-kotoran dan lain sebagainnya. Sebagaimana Firman Allah SWT dalam surat Al Maidah ayat 3,

Artinya : "Diharamkan bagi kamu sekalian bangkai, darah, daging babi, dan binatang yang disembelih denan tidak atas nama Allah, binatang yang tercekik, yang dipukul, yang terjatuh, yang ditanduk, yang tertekam binatang buas keuali kamu sempat menyembelihnya, dan diharamkan juga bagimu binatang yang disembelih untuk dipersembahkan kepada berhala." (Q.S. Al Maidah: 3)

Kosmetik yang digunakan sehari-hari akan menempel pada tubuh dan akan mendarah dagingpada tubuh manusia. Setiap muslim diperintahkan untuk menggunakan atau mengkonsumsi produk yang halalan thoyibban (halal lagi baik). Baik dipandang memberikan manfaat dan tidak berbahaya.Kehalalan suatu produk tidak hanya untuk makanan dan minuman namun juga kosmetik yang walaupun hanya untuk pemakaian luar harus menggunakan kosmetik yang halal.

\section{Promosi}

Ekonomi Islam juga menerapkan promosi yang dilakukan untuk menawarkan, menginformasikan, menjual produk atau jasa di pasar.Promosi yang digunakan oleh Nabi Muhammad Saw, adalah personal selling, iklan, promosi penjualan dan humas.Namun cara-cara yang ditetapkan oleh Nabi Muhammad Saw berbeda dengan promosi yang dilakukan pada saat ini. Kebanyakan promosi yang dilakukan saat ini banyak yang tidak sesuai dengan apa yang dikatakan dalam iklan, bahkan terkadang promosi sekarang menjatuhkan atau menjelekkan produk-produk pesaingnya, cara ini jelas melanggar syariat Islam. Cara yang dilakukkan Nabi Muhammad Saw tidak terlepas dari nilai-nilai moralitas, yaitu dengan menjaga kepercayaan pelanggan, berpenampilan menawan, mengutamakan pelanggan, tidak mengambil untung yang berlebihan, dan sebagainya.Menurut prinsip syariah, kegiatan pemasaran harus dilandasi dengan semangat untuk beribadah kepada Allah SWT, berusaha semaksimal 
mungkin untuk kesejahteraan bersama, bukan hanya untuk kepentingan golongan apalagi untuk kepentingan pribadi. (Susanti, 2016)

Firman Allah SWT dalam Al Quran surat An Nisa' ayat 29:

Artinya: "Hai orang-orang yang beriman, janganlah kamu saling memakan harta sesamamu dengan jalan yang bathil, kecuali dengan jalan perniagaan yang berlaku dengan suka sama suka di antara kamu, dan janganlah kamu membunuh dirimu.Sesungguhnya Allah adalah Maha Penyayang kepadamu."(Q.S.An Nisa': 29)

Ayat ini menerangkan bahwa Allah SWT mengharamkan kita untuk memakan harga dengan jalan bathil dan dengan melakukan tindakan menipu baik dengan cara lisan maupun perbuatan itu termasuk memakan harta dengan jalan yang bathil karena adanya unsur ketidak relaan.

\section{Harga}

Harga hanya terjadi pada akad, yakni sesuatu yang direlakan dalam akad, baik lebih sedikit, lebih besar, atau sama dengan nilai barang. Biasanya, harga dijadikan penukar barang yang diridhai oleh kedua pihak yang akad (Syafei, 2000: 87).Dari pengertian tersebut dijelaskan bahwa harga merupakan kesepakatan mengenai transaksi jual beli barang atau jasa di mana kesepakatan harus diridhai oleh kedua belah pihak.

Ibnu Taimiyah menatakan "Besar kecilnya kenaikan harga bergantung pada besarnya perubahan penawaran dan atau permintaan. Bila seluruh transaksi sudah sesuai aturan, kenaikan harga yang terjadi merupakan kehendak Allah".

\section{Penelitian Terdahulu}

Sebelum dilakukannya penelitian ini, telah ada beberapa penelitian dengan tema yang berhubungan dengan penelitian ini. Adapun penelitian-penelitian terdahulu yang dapat memberikan masukan bagi peneliti.terdapat beberapa perbedaan dalam penelitian ini dengan penelitian-penelitian sebelumnya yaitu pada variabel penelitian, objek penelitian dan periode waktu yang digunakan. Penelitian ini mereplikasi penelitian yang dilakukan oleh Desi Rimika Amanda Sari (2019) yang berjudul Pengaruh Label Halal, Harga dan Citra Merek terhadap Keputusan Pembelian Produk Kosmetik Wardah Pada Mahasiswi Fakultas Ekonomi dan Bisnis Islam IAIN Tulungagung. Perbedaan dalam penelitian ini dengan penelitian tersebut terletak pada variabel, objek penelitian yang digunakan dan tahun penelitian.Variabel dalam penelitian ini yaitu Pengetahuan Produk, Label Halal dan Promosi sebagai variabel independen dan dengan menambahkan Harga sebagai variabel Mediasi.Persamaan dalam penelitian ini yaitu pada Label Halal sebagai variabel independen dan Keputusan Pembelian sebagai variabel dependen.

\section{Kerangka Pemikiran dan Hipotesis}

Untuk memperjelas penelitian dan mempermudah dalam pemahaman, maka dapat digambarkan suatu pemikiran teoritis sebagai berikut:

\section{Gambar 2 Kerangka Pemikiran Teoritis}




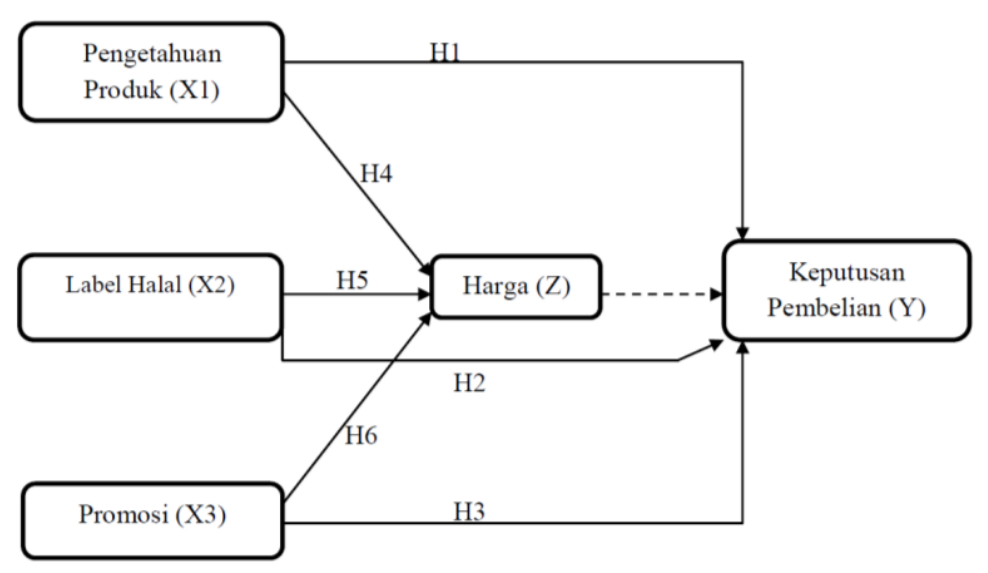

1. Pengetahuan produk yaitu pengetahuan konsumen akan suatu produk yang berkaitan dengan ciri atau karakter pada produk yang membuatkonsumen dapat membedakan suatu produk dengan produk lainnya. Sebelum membeli sebuah produk lebih baik konsumen mengerti kegunaan dan manfaat yang terkandung dalam produk agar dalam pemakaian jangka panjang tidak membahayakan tubuh konsumen dan dapat digunakan sesuai dengan kebutuhan.. Trizki Lastyawati (2019) meneliti Pengaruh Pengetahuan Produk, Harga, Dukungan Selebriti, Gaya Hidup dan Word Of Mouth terhadap Keputusan Pembelian Kosmetik Wardah di Surabaya menunjukkan bahwa pengetahuan produk berpengaruh secara signifikan terhadap keputusan pembelian. Dari penjelasan di atas maka dapat diambil hipotesis:

$\mathrm{H}_{1}$ : Pengetahuan produk berpengaruh signifikan terhadap keputusan pembelian produk kosmetik halal.

2. Label Halal merupakan pernyataan yang menempel pada kemasan produk untuk menunjukkan bahwa produk tersebut sudah berstatus sebagai produk halal. Sebelum mendapatkan label halal, harus memperoleh sertifikat halal dimana sertifikat halal merupakan syarat untuk mendapatkan ijin pencantuman label halal pada kemasan produk. Label halal menjadi penting untuk suatu produk karena akan memastikan bahwa produk tersebut aman dengan tidak menggunakan bahan yang dapat membahayakan tubuh, label halal juga akan menjelaskan bahan dalam produk tersebut tidak mengandung yang di haramkan dalam Al Qur'an seperti alkohol dan yang berasal dari tubuh hewan.Ratih Hesty Utami Puspitasari (2019) meneliti Analisis Pengaruh Keputusan Pembelian Pada Kosmetik Berlabel Halal menunjukkan bahwa label halal berpengaruh positif terhadap keputusan pembelian.

$\mathrm{H}_{2}$ : Label halal berpengaruh signifikan terhadap keputusan pembelian produk kosmetik halal.

3. Promosi adalah segala sesuatu yang dilakukan penjual baik dengan perbuatan untuk memperkenalkan barang dagangan atau layanan untuk mendorong dan menarik minat orang lain untuk membelinya.Promosi menjadi penting karena promosi dapat membuat orang menjadi paham dan 
mengerti tentang suatu produk baik dari kegunaan dan manfaatnya. Dalam promosi biasanya perusahaan membagikan brosur, mengikuti event-event tertentu, membagikan produk atau biasa disebut tester dan memasang spanduk di jalan raya. Pada jaman sekarang cara melakukan promosi sangat di mudahkan dengan adanya media sosial, perusahaan dapat memanfaatkan media sosial untuk melakukan promosi dengan mudah dan murah.Novie Agung Trihandono (2020) meneliti Pengaruh Kualitas Produk, Persepsi Harga Dan Promosi Terhadap Keputusan Pembelian Kosmetik Herborist (Studi Empiris Pada Konsumen PT. Victoria Care Indonesia Semarang) menunjukkan bahwa promosi berpengaruh positif dan signifikan terhadap keputusan pembelian. Dari penjelasan di atas maka dapat diambil hipotesis:

$\mathrm{H}_{3}$ : Promosi berpengaruh signifikan terhadap keputuan pembelian produk kosmetik halal.

4. Produk adalah segala sesuatu baik barang ataupun jasa yang ditawarkan guna untuk memenuhi kebutuhan dan keinginan manusia dimana setiap barang atau jasa tersebut memiliki manfaat yang berbeda. Pengetahuan produk merupakan pengetahuan konsumen atau calon pembeli akan informasi sesuatu produk yang akan di beli sehingga informasi yang didapat pada suatuproduk itu akan bermacam-macam. Pada saat konsumen mengetahui kegunaan dan manfaat dari suatu produk, konsumen akan mempertimbangkan apakah manfaat dan kualitas sesuai dengan harga yang ditawarkan.Adelina Nur Zalisa (2019) meneliti Pengaruh Perilaku Religiusitas Dan Pengetahuan Produk Terhadap Konsumen Dan Keputusan Pembelian Pada Produk Kosmetik Halal menunjukkan bahwa pengetahuan produk berpengaruh positif terhadap keputusan pembelian.Pengetahuan konsumen akan suatu produk didasarkan atas informasi mengenai produk yang melekat di benak konsumen. Dari penjelasan di atas maka dapat diambil hipotesis:

$\mathrm{H}_{4}$ : Pengetahuan produk mempunyai pengaruh signifikan terhadap keputusan pembelian dengan harga sebagai variabel mediasi.

5. Label merupakan bagian yang tidak bisa dipisahkan dari suatu produk untuk menyampaikan informasi mengenai penjualan. Label halal merupakan pernyataan mengenai kejelasan suatu produk yang melekat pada kemasan untuk meyakinkan konsumen bahwa produk tersebut telah mendapatkan sertifikat halal. Dalam pemilihan suatu produk, konsumen yang memiliki pemahaman agama akan lebih selektif saat memutuskan membeli suatu produk dengan meneliti apakah dalam kemasan tersebut terdapat label halal. Sebelum melakukan pembelian lebih baik konsumen memeriksa, mencari tahu atau menanyakan kepada penjual tentang kehalalan akan suatu produk terlebih produk yang akan digunakan untuk tubuh manusia.Elin Intan Anggraini dkk (2019) meneliti Pengaruh Kualitas Produk Dan Harga Terhadap Keputuan Pembelian (Survei pada Pembeli yang juga Menggunakan Kosmetik Wardah Di Counter Wardah Matahari Departemen Store Malang Town Square) menunjukkan bahwa harga secara pasrial 
berpengaruh signifikan terhadap keputusan pembelian.Dari penjelasan di atas maka dapat diambil hipotesis:

$\mathrm{H}_{5}$ : Label halal mempunyai pengaruh signifikan terhadap keputusan pembelian dengan harga sebagai variabel mediasi

6. Promosi adalah semua jenis kegiatan pemasaran yang ditujukan untuk mendorong permintaan (Swastha dan Irawan. 2003: 349). Dalam mempromosikan dagangan dapat menggunakan berbagai sarana baik lisan ataupun tertulis dan bisa menggunakan media sosial yang saat ini banyak digunakan oleh manusia. Perusahaan atau pedagang harus bisa memberikan promosi yang menarik agar konsumen tertarik dengan suatu produk tersebut, pada saat melakukan promosi akan lebih baik apabila perusahaan atau pedagang mencantumkan harga karena merupakan unsur penting dalam penjualan yang akan membuat kesan baik atau buruk kepada konsumen dilihat dari manfaat dan kualitasnya.Syafrida Hafni Sahir (2016) Pengaruh Gaya Hidup, Label Halal Dan Harga Terhadap Keputusan Pembelian Kosmetik Wardah Pada Mahasiswa Program Studi Manajemen Fakultas Ekonomi Universitas Area Medan menunjukkan bahwa harga secara parsial berpengaruh positif dan signifikan terhadap keputusan pembelian. Dari penjelasan di atas maka dapat diambil hipotesis:

$\mathrm{H}_{6}$ : Promosi mempunyai pengaruh signifikan terhadap keputusan pembelian dengan harga sebagai variabel mediasi.

\section{METODE PENELITIAN}

\section{Desain Penelitian}

Pendekatan yang digunakan dalam penelitian ini pendekatan kuantitatif.Penelitian kuantitatif dapat diartikan sebagai metode penelitian yang berlandaskan filsafat positifisme.Metode ini digunakan untuk meneliti pada populasi atau sampel tertentu, pengumpulan data menggunakan instrument penelitian analisis data bersifat kuantitatif/statistik, dengan tujuan untuk menguji hipotesis yang telah ditetapkan (Sugiyono, 2012: 11).

Dalam penelitian ini menggunakan data primer yang diperoleh dari sumber secara langsung dari responden melalui kuesioner.Objek penelitian yang diteliti adalah mahasiswi Fakultas Ekonomika dan Bisnis Universitas Muhammadiyah Pekajangan Pekalongan.

\section{Populasi dan Sampel Penelitian}

Populasi merupakan suatu universe, yaitu generalisasi yang terdiri atas subjek yang mempunyai kuantitas dan karakteristik tertentu yang di tetapkan oleh peneliti untuk dipelajari dan kemudian ditarik kesimpulannya (Nurhayati, 2012: 36).Populasi dalam penelitian ini adalah mahasiswi Fakultas Ekonomika dan Bisnis Universitas Muhammadiyah Pekajangan Pekalongan yang berjumlah 364 mahasiswi.Sampel merupakan wakil populasi atau sebagian dari populasi yang akan diteliti. Teknik pengambilan sampel dalam penelitian ini yaitu dengan menggunakan Purposive sampling. Selanjutnya untuk pengambilan 
jumlah sampel menggunakan rumus Slovin dengan jumlah sampel 100 responden.

\section{Variabel Penelitian dan Definisi Operasional}

\section{Variabel Terikat (variabel dependen)}

Variabel terikat (dependent variable) merupakan variabel yang diakibatkan atau dipengaruhi oleh variabel bebas. Variabel dependen dalam penelitian ini adalah Keputusan Pembelian.

2. Variabel Bebas (variabel independen)

Variabel bebas (independent variable) merupakan variabel yang mempengaruhi atau menjelaskan terhadap variabel terikat (variabel dependen).Variabel independen dalam penelitian ini adalah Pengetahuan produk, Label Halal dan Promosi.

\section{Pengetahuan Produk}

Pengetahuan produk adalah pengetahuan konsumen yang berkaitan dengan pengetahuan tentang ciri atau karakter produk, konsekuensi menggunakan produk dan nilai tingkat kepuasan yang akan dicapai oleh produk. (Peter dan Olson, 1999)

\section{Label Halal}

Halal berarti hal-hal yang boleh dan dapat dilakukan karena bebas atau tidak terikat dengan ketentuan-ketentuan yang melarangnya (Qardhawi, 2007: 5).

\section{Promosi}

Promosi adalah cara untuk memberitahu, menginformasikan atau menawarkan produk atau jasa dengan tujuan untuk menarik konsumen agar membeli atau tetap bertahan dalam menggunakan produk atau jasa tersebut.

3. Variabel Mediasi

Variabel mediasi atau intervening adalah variabel yang secara teoritis dapat mempengaruhi hubungan kausal antara variabel bebas terhadap variabel terikat.Variabel ini terletak di antara variabel independen dan dependen, sehingga variabel independen tidak secara langsung mempengaruhi variabel dependen.

\section{Harga}

Harga adalah suatu nilai tukar yang bisa disamakan dengan uang atau barang lain untuk manfaat yang diperoleh dari suatu barang atau jasa oleh seseorang atau kelompok pada waktu tertentu (Sudaryono, 2016: 216).

\section{Lokasi Penelitian}

Penelitian ini dilakukan pada mahasiswi di Fakultas Ekonomika dan Bisnis Universitas Muhammadiyah Pekajangan Pekalongan, Jl. KHM.Mansyur No. 2 Bendan Pekalongan Barat.

\section{Prosedur Pengumpulan Data}

Metode pengumpulan data yang digunakan dalam penelitian ini adalah menggunakan kuesioner (sebagai data primer) yang dibagikan langsung 
kepada responden.Kuesioner berisi beberapa pertanyaan yang terkait dengan pengetahuan produk, label halal dan promosi dalam kuesioner terdapat petunjuk pengisian dan petunjuk umum sehingga mudah untuk dimengerti dan dipahami oleh responden. Skala yang digunakan dalam kuesioner adalah skala likert dengan lima kategori yaitu, sangat setuju, setuju, ragu-ragu, tidak setuju, sangat tidak setuju.

\section{Teknik Penelitian}

1. Analisis Statistik Deskriptif

Untuk memberikan gambaran umum mengenai demografi responden (jenis kelamin, pendidikan, lama bekerja) dan deskriptif mengenai variabel penelitian.

2. Uji Validitas

Validitas adalah suatu ukuran yang menunjukan tingkat kevalidan (Arikunto, 1998:158).Syarat untuk dianggap memenuhi kriteria valid apabila $\mathrm{r}$ hitung $>\mathrm{r}$ tabel. Sedangkan apabila $\mathrm{r}$ hitung $<\mathrm{r}$ tabel, maka kriteria tidak valid (Sugiyono,2001).

3. Uji Reliabilitas

Uji reliabilitas adalah alat untuk mengukur suatu kuesioner yang merupakan indikator dari variabel atas konstruk. Suatu kuesioner dikatakan reliabel adalah suatu kuesioner yang apabila dicobakan secara berulangulang kepada kelompok yang sama akan menghasilkan data yang sama.

4. Uji Asumsi Klasik, terdiri dari:

a. Uji Normalitas

Tujuan dari uji normalitas adalah untuk menguji apakah dalam model regresi, variabel bebas dan variabel terikat masing-masing datanya berdistribusi normal atau tidak. Uji normalitas data menggunakan Kolmogorov Smirnov Test, dengan taraf signifikan 0.05.Dasar penarikan kesimpulan adalah data dikatakan berdistribusi normal apabila asymp.Significance lebih besar dari 0.05 .

b. Uji Multikolonieritas

Menurut Ghozali (2011) uji multikolonieritas bertujuan untuk mendeteksi apakah variabel independen pada model regresi daling berkorelasi, dengan menggunakan nilai tolerance dan lawannya yaitu Variance Inflation Factor (VIF). Batas tolerance value adalah 0.1 dan VIF adalah 10. Terjadi gejala multikolonieritas ketika nilai toleransi $<0.1$ dan VIF $>10$. Adapun hasil uji multikolonieritas dalam penilitian ini sebagai berikut:

c. Uji Heteroskedastisitas

Dalam penelitian ini, uji statistik yang digunakan untuk menguji heteroskedastisitas adalah uji Glejser, yaitu meregresi nilai absolut residual terhadap variabel independen dengan menggunakan persamaan regresi. Jika variabel independen signifikan secara statistik memengaruhi variabel dependen, maka ada indikasi terjadi heteroskedastisitas, jika nilai 
signifikansinya diatas 0.05 maka dapat ditarik kesimpulan bahwa regresi tidak mengandung heteroskedastisitas (Ghozali, 2013: 143).

5. Uji Signifikansi Parameter Individual (Uji Statistik $t$ )

Uji statistik $t$ digunakan untuk menguji pengaruh dari masing-masing variabel bebas (pengetahuan produk, label halal dan promosi).

6. Analisis Jalur (Path Analysis)

Menurut Ghozali (2009), analisis jalur merupakan perluasan dari analisis regresi linier berganda, atau analisis jalur adalah penggunaan analisis regresi untuk menaksir hubungan kausalitas antar variabel yang telah ditetapkan sebelumnya berdasarkan teori. Teknik analisis jalur digunakan untuk mencari pengaruh dari variabel Pengetahuan Produk dan Label Halal terhadap Keputusan Pembelian dengan variabel Harga sebagai variabel mediasi (penghubung).

7. Uji Sobel Test

Sobel tes digunakan untuk mengetahui pengaruh variabel mediasi yaitu Harga. Menurut Ghozali (2011) suatu variabel disebut variabel intervening jika variabel tersebut ikut mempengaruhi hubungan antara variabel independen dan variabel dependen.

8. Uji Koefisien Determinasi (Uji R2)

Koefisien determinasi $\left(R^{2}\right)$ pada intinya mengukur seberapa jauh kemampuan model dalam menerangkan variasi variabel dependen.Nilai koefisien determinasi adalah nol atau satu.

\section{HASIL DAN PEMBAHASAN}

\section{Deskripsi Hasil Penelitian}

Data dalam penelitian ini dikumpulkan dengan menyebarkan kuesioner kepada mahasiswi Fakultas Ekonomika Dan Bisnis Universitas Muhammadiyah Pekajangan Pekalongan. Adapun rincian penyebaran kuesioner sebagai berikut:

Tabel 1 Hasil Analisis Jumlah Responden

\begin{tabular}{|l|l|c|}
\hline \multicolumn{1}{|c|}{ No } & \multicolumn{1}{|c|}{ Keterangan } & Jumlah \\
\hline 1. & Kuesioner yang disebar & 100 \\
\hline 2. & Kuesioner yang tidak dapat diolah & 0 \\
\hline 3. & Kuesioner yang dapat diolah & 100 \\
\hline
\end{tabular}

Sumber : Data primer yang diolah 2020

Dari hasil penyebaran kuesioner diketahui dari 100 kuesioner yang disebar dapat diolah semua karena dapat kembali sesuai dengan kuesioner yang telah disebarkan.

\section{Analisis Karakteristik Responden}

1. Berdasarkan Usia

Deskripsi karakteristik responden berdasarkan usiadisajikan pada tabel dibawah ini:

Tabel 2 Karakteristik Responden Berdasarkan Usia 


\begin{tabular}{|c|c|c|c|}
\hline No & Usia & Frekuensi & Presentase \\
\hline 1. & $15-20$ tahun & 22 & $22 \%$ \\
\hline 2. & $21-25$ tahun & 77 & $77 \%$ \\
\hline 3. & $26-30$ tahun & 1 & $1 \%$ \\
\hline \multicolumn{2}{|c|}{ Jumlah } & 100 & $100 \%$ \\
\hline
\end{tabular}

Sumber : Data primer yang diolah 2020

\section{Program Studi}

Deskripsi karakteristik responden berdasarkan program studi disajikan pada tabel dibawah ini:

Tabel 3 Karakteristik Responden Berdasarkan Program Studi

\begin{tabular}{|c|c|c|c|}
\hline No & Program Studi & Frekuensi & Presentase \\
\hline 1. & D3 Akuntansi & 7 & $7 \%$ \\
\hline 2. & S1 Akuntansi & 37 & $37 \%$ \\
\hline 3. & S1 Ekonomi Syariah & 27 & $27 \%$ \\
\hline 4. & S1 Manajemen & 29 & $29 \%$ \\
\hline \multicolumn{2}{|c|}{ Jumlah } & 100 & $100 \%$ \\
\hline
\end{tabular}

Sumber: Data primer yang diolah 2020

\section{Deskripsi Variabel Penelitian}

Tabel 4 Jawaban responden pada variabel pengetahuan produk, label halal, promosi, keputusan pembelian dan harga

\begin{tabular}{|c|c|c|c|c|c|c|}
\hline No. & Variabel & STS & TS & KS & $S$ & SS \\
\hline \multirow[t]{2}{*}{1.} & \multirow{2}{*}{$\begin{array}{l}\text { Pengetahuan } \\
\text { Produk (X1) }\end{array}$} & 1 & 2 & 6 & 129 & 162 \\
\hline & & $0,3 \%$ & $0,6 \%$ & $2 \%$ & $43 \%$ & $54 \%$ \\
\hline \multirow[t]{2}{*}{2.} & \multirow[t]{2}{*}{ Label Halal(X2) } & 3 & 2 & 19 & 149 & 127 \\
\hline & & $1 \%$ & $0,6 \%$ & $6,3 \%$ & $49,6 \%$ & $42,3 \%$ \\
\hline \multirow[t]{2}{*}{3.} & \multirow[t]{2}{*}{ Promosi (X3) } & 2 & 5 & 82 & 266 & 145 \\
\hline & & $0,6 \%$ & $1,6 \%$ & $27,3 \%$ & $88,6 \%$ & $48,3 \%$ \\
\hline \multirow[t]{2}{*}{4.} & \multirow{2}{*}{$\begin{array}{l}\text { Keputusan } \\
\text { Pembelian }(Y)\end{array}$} & 4 & 0 & 10 & 116 & 164 \\
\hline & & $1,3 \%$ & $0,0 \%$ & $3,3 \%$ & $38,6 \%$ & $54,6 \%$ \\
\hline \multirow[t]{2}{*}{5.} & \multirow[t]{2}{*}{ Harga $(Z)$} & 1 & 2 & 20 & 136 & 135 \\
\hline & & $0,3 \%$ & $0,6 \%$ & $6,6 \%$ & $45,3 \%$ & $45 \%$ \\
\hline
\end{tabular}

\section{Hasil Analisis Data}

Berikut ini disajikan tabel analisis statistik deskriptif pada masing-masing variabel yaitu:

\section{Tabel 5 Uji Statistik Deskriptif \\ Descriptive Statistics}

\begin{tabular}{|l|r|r|r|r|r|}
\hline & N & Minimum & Maximum & Mean & Std. Deviation \\
\hline Pengetahuan Produk & 100 & 6.00 & 15.00 & 13.4900 & 1.45987 \\
Label Halal & 100 & 4.00 & 15.00 & 12.9500 & 1.67196 \\
Promosi & 100 & 10.00 & 25.00 & 20.4700 & 2.46370 \\
Harga & 100 & 5.00 & 15.00 & 13.1400 & 1.52435 \\
Keputusan & 100 & 3.00 & 15.00 & 13.4800 & 1.50071 \\
Pembelian & & & & & \\
\hline
\end{tabular}


Descriptive Statistics

\begin{tabular}{|l|r|r|r|r|r|}
\hline & N & Minimum & Maximum & Mean & Std. Deviation \\
\hline Pengetahuan Produk & 100 & 6.00 & 15.00 & 13.4900 & 1.45987 \\
Label Halal & 100 & 4.00 & 15.00 & 12.9500 & 1.67196 \\
Promosi & 100 & 10.00 & 25.00 & 20.4700 & 2.46370 \\
Harga & 100 & 5.00 & 15.00 & 13.1400 & 1.52435 \\
Keputusan & 100 & 3.00 & 15.00 & 13.4800 & 1.50071 \\
Pembelian & & & & & \\
Valid N (listwise) & 100 & & & & \\
\hline
\end{tabular}

Sumber: Data primer yang diolah 2020

\section{Uji Validitas Dan Uji Reliabilitas}

\section{Uji Validitas}

Adapun hasil uji validitas dapat dilihat pada tabel sebagai berikut:

Tabel 6 Hasil Uji Validitas

\begin{tabular}{|c|c|c|c|c|}
\hline Variabel & Item & r hitung & r tabel & Kriteria \\
\hline Pengetahuan Produk & X1.1 & 0.769 & 0.1966 & Valid \\
(X1) & X1.2 & 0.833 & 0.1966 & Valid \\
& X1.3 & 0.821 & 0.1966 & Valid \\
\hline Label Halal & X2.1 & 0.830 & 0.1966 & Valid \\
(X2) & X2.2 & 0.808 & 0.1966 & Valid \\
& X2.3 & 0.728 & 0.1966 & Valid \\
\hline Promosi & X3.1 & 0.646 & 0.1966 & Valid \\
(X3) & X3.2 & 0.722 & 0.1966 & Valid \\
& X3.3 & 0.696 & 0.1966 & Valid \\
& X3.4 & 0.688 & 0.1966 & Valid \\
& X3.5 & 0.793 & 0.1966 & Valid \\
\hline Harga & Z.1 & 0.718 & 0.1966 & Valid \\
(Z) & Z.2 & 0.747 & 0.1966 & Valid \\
& Z.3 & 0.810 & 0.1966 & Valid \\
\hline Keputusan Membeli & Y.1 & 0.771 & 0.1966 & Valid \\
(Y) & Y.2 & 0.780 & 0.1966 & Valid \\
& Y.3 & 0.806 & 0.1966 & Valid \\
\hline
\end{tabular}

Sumber: Data primer yang diolah 2020

Berdasarkan tabel 6 dapat dapat diketahui bahwa semua item pernyataan untuk semua variabel Pengetahuan Produk, Label Halal, Promosi, Keputusan Membeli dan Harga memiliki $r$ hitung $>$ r tabel $(\mathrm{df}=\mathrm{N}-2$ $=100-2=98$, pada tingkat signifikansi uji dua arah 0.05) mendapatkan nilai $\mathrm{r}$ tabel 0.1966 . Dengan demikian semua pernyataan bersifat valid dan dapat digunakan sebagai alat ukur dalam penelitian ini.

2. Uji Reliabilitas

Tabel 7 Hasil Uji Reliabilitas

\begin{tabular}{|c|c|c|c|c|}
\hline No. & Variabel & Cronbach's Alpha & Kriteria standar & Kesimpulan \\
\hline 1. & Pengetahuan Produk & 0,734 & 0,60 & Reliabel \\
\hline
\end{tabular}




\begin{tabular}{|c|l|l|l|l|}
\hline 2. & Label Halal & 0,698 & 0,60 & Reliabel \\
\hline 3. & Promosi & 0,754 & 0,60 & Reliabel \\
\hline 4. & Keputusan Pembelian & 0,690 & 0,60 & Reliabel \\
\hline 5. & Harga & 0,624 & 0,60 & Reliabel \\
\hline 6. & Keputusan Nasabah & 0,775 & 0,60 & Reliabel \\
\hline
\end{tabular}

Sumber: Data primer yang diolah (2020)

Berdasarkan tabel 7 diatas diketahui bahwa semua variabel dalam penelitian ini memiliki nilai Cronbach Alpha> 0.60.Sehingga semua varibel dapat dikatakan reliabel dan handal yang bisa digunakan dalam penelitian ini.

\section{Uji Asumsi Klasik}

1. Uji Normalitas

Tabel 8 Hasil Uji Normalitas

One-Sample Kolmogorov-Smirnov Test

\begin{tabular}{|ll|r|}
\hline & & $\begin{array}{c}\text { Unstandardized } \\
\text { Residual }\end{array}$ \\
\hline Normal Parametersa ${ }^{\mathrm{\prime}} \mathrm{b}$ & $\mathrm{N}$ & 100 \\
& Mean & .0000000 \\
Most Extreme & Std. Deviation & .07312637 \\
Differences & Absolute & .060 \\
& Positive & .045 \\
& Negative & -.060 \\
& Kolmogorov-Smirnov Z & .597 \\
& Asymp. Sig. (2-tailed) & .869 \\
\hline
\end{tabular}

a. Test distribution is Normal.

b. Calculated from data.

Sumber: Data primer yang diolah 2020

Berdasarkan tabel 4.20, diperoleh nilai Asymp. Sig (2-tailed) residual sebesar $0.869>0.05$, maka dapat disimpulkan bahwa seluruh data dalam penelitian ini berdistribusi normal.

2. Uji Multikolonieritas

Tabel 9 Hasil Uji Multikolinieritas

Coefficients $^{\mathrm{a}}$

\begin{tabular}{|ll|r|c|}
\hline \multirow{2}{*}{ Model } & \multicolumn{2}{|c|}{ Collinearity Statistics } \\
\cline { 2 - 4 } & Tolerance & \multicolumn{1}{c|}{ VIF } \\
\hline $1 \quad$ Pengetahuan & .553 & 1.808 \\
& Produk & & \\
& Label Halal & .555 & 1.803 \\
& Promosi & .733 & 1.364 \\
\hline
\end{tabular}




\section{\begin{tabular}{|l|l|l|}
\hline Harga & .519 & 1.927 \\
\hline
\end{tabular}}

Sumber: Data primer yang diolah (2020)

Berdasarkan tabel 4.21 menunjukkan bahwa semua variabel memiliki nilai tolerance lebih dari 0.1 dan nilai VIF kurang dari 10. Sehingga dapat disimpulkan bahwa model regresi tersebut tidak terjadi multikolonieritas.

3. Uji Heteroskedastisitas

Tabel 10 Hasil Uji Heteroskedastisitas

Coefficients ${ }^{a}$

\begin{tabular}{|c|c|c|c|c|c|}
\hline \multirow[b]{2}{*}{ Model } & \multicolumn{2}{|c|}{ Unstandardized Coefficients } & \multirow{2}{*}{$\begin{array}{c}\text { Standardized Coefficients } \\
\text { Beta }\end{array}$} & \multirow[b]{2}{*}{$\mathrm{t}$} & \multirow[b]{2}{*}{ Sig. } \\
\hline & B & Std. Error & & & \\
\hline (Constant) & .223 & .052 & & 4.293 & .000 \\
\hline Pengetahuan Produk & -.001 & .065 & -.003 & -.023 & .982 \\
\hline Label Halal & .017 & .048 & .060 & .350 & .728 \\
\hline Promosi & -.066 & .059 & -.199 & -1.132 & .265 \\
\hline Harga & .084 & .064 & .169 & 1.306 & .195 \\
\hline
\end{tabular}

a. Dependent Variable: abs_res1

Sumber: Data primer yang diolah 2020

Berdasarkan tabel 4.22 dapat diketahui bahwa nilai signifikansi berada diatas level of signifance $5 \%$ atau 0.05 , yaitu variabel pengetahuan produk $\left(X_{1}\right)$ sebesar 0.982, label halal $\left(\mathrm{X}_{2}\right)$ sebesar 0.728 dan promosi $\left(\mathrm{X}_{3}\right)$ sebesar 0.26 , sehingga dapat dikatakan variabel independen tidak terjadi heteroskedastisitas.

\section{Uji Hipotesis}

1. Uji Parsial (Uji t)

Tabel 11 Uji Signifikansi Parameter Individual (Uji t)

Coefficients $^{\mathrm{a}}$

\begin{tabular}{|ll|r|r|r|r|r|}
\hline \multirow{2}{*}{ Model } & \multicolumn{2}{|c|}{$\begin{array}{c}\text { Unstandardized } \\
\text { Coefficients }\end{array}$} & $\begin{array}{c}\text { Standardized } \\
\text { Coefficients }\end{array}$ & \multicolumn{2}{|c|}{} \\
\cline { 2 - 7 } & \multicolumn{1}{|c|}{$\mathrm{B}$} & Std. Error & \multicolumn{1}{c|}{ Beta } & \multicolumn{1}{c|}{$\mathrm{t}$} & \multicolumn{1}{c|}{ Sig. } \\
\hline 1 & (Constant) & .142 & .080 & & 1.777 & .079 \\
& Pengetahuan Produk & .223 & .100 & .217 & 2.222 & .029 \\
& Label Halal & .178 & .088 & .199 & 2.036 & .045 \\
& Promosi & .200 & .086 & .198 & 2.334 & .022 \\
& Harga & .271 & .099 & .277 & 2.742 & .007 \\
\hline
\end{tabular}

a. Dependent Variable: Keputusan Pembelian

Sumber: Data primer yang diolah 2020

Adapun penjelasannya adalah sebagai berikut:

1. Pengaruh Pengetahuan Produk terhadap Keputusan Pembelian Produk Kosmetik Halal 
Berdasarkan tabel 4.23 diketahui bahwa nilai signifikansi variabel pengetahuan produk sebesar 0.029 atau $0.029<0.05$. Sehingga H1 diterima, artinya Pengetahuan Produk berpengaruh signifikan terhadap keputusan pembelian produk kosmetik halal.

2. Pengaruh Label Halal terhadap Keputusan Pembelian Produk Kosmetik Halal

Berdasarkan tabel 4.23 diketahui bahwa nilai signifikan variabel Label Halal sebesar 0.045 atau $0.045<0.05$. Sehingga H2 diterima, artinya Label Halal berpengaruh signifikan terhadap keputusan pembelian produk kosmetik halal.

3. Pengaruh Promosi terhadap Keputusan Pembelian Produk Kosmetik Halal

Berdasarkan tabel 4.23 diketahui bahwa nilai signifikan variabel promosi sebesar 0.022 atau $0.022<0.05$. Sehingga H3 diterima, artinya Promosi berpengaruh signifikan terhadap keputusan pembelian produk kosmetik halal.

2. Uji Analisis Jalur

Tabel 12 Pembentukan Jalur I

Coefficients ${ }^{a}$

\begin{tabular}{|c|c|c|c|c|c|c|}
\hline \multirow{2}{*}{\multicolumn{2}{|c|}{ Model }} & \multicolumn{2}{|c|}{ Unstandardized Coefficients } & \multirow{2}{*}{$\begin{array}{c}\begin{array}{c}\text { Standardized } \\
\text { Coefficients }\end{array} \\
\text { Beta }\end{array}$} & \multirow[b]{2}{*}{$\mathrm{t}$} & \multirow{2}{*}{ Sig. } \\
\hline & & B & Std. Error & & & \\
\hline \multirow[t]{4}{*}{1} & (Constant) & .115 & .082 & & 1.408 & .162 \\
\hline & Pengetahuan Produk & .329 & .098 & .314 & 3.357 & .001 \\
\hline & Label Halal & .236 & .087 & .257 & 2.701 & .008 \\
\hline & Promosi & .320 & .082 & .310 & 3.889 & .000 \\
\hline
\end{tabular}

a. Dependent Variable: Harga

Sumber: Data primer yang diolah 2020

Hasil output SPSS pada tabel 4.24 memberikan nilai standardized beta pengetahuan produk sebesar 0.314 dengan nilai Sig 0.01, label halal 0.257 dengan nilai Sig. 0.08 dan promosi 0.310 dengan nilai Sig. 0.00 .

\section{Tabel 13 Nilai R square}

\begin{tabular}{l|r|r|r|c|}
\hline Model & \multicolumn{1}{|c|}{ Model Summary } \\
\hline 1 & R Square & $\begin{array}{c}\text { Adjusted R } \\
\text { Square }\end{array}$ & $\begin{array}{c}\text { Std. Error of the } \\
\text { Estimate }\end{array}$ \\
\hline
\end{tabular}
a. Predictors: (Constant), Promosi, Pengetahuan Produk, Label Halal
b. Dependent Variable: Harga

Sumber: Data primer yang diolah 2020

Berdasarkan tabel 4.25 maka dapat diketahui bahwa nilai Adjusted $R$ square sebesar 0.481 atau $48.1 \%$. hal tersebut menunjukkan bahwa variabel independen yaitu pengetahuan produk, label halal dan promosi mampu menjelaskan $48.1 \%$ dari variabel keputusan pembelian. 
Berdasarkan tabel diatas nilai $\mathrm{e}_{1}$ sebesar:

$$
\begin{aligned}
& \mathrm{e}_{1}=\sqrt{1-R^{2}} \\
& \mathrm{e}_{1}=\sqrt{1-0.481} \\
& \mathrm{e}_{1}=0.721
\end{aligned}
$$

Berdasarkan perhitungan tersebut diketahui bahwa $\mathrm{e}_{1}$ cukup besar yaitu 0.721, hal tersebut memiliki arti bahwa pengaruh variabel diluar penelitian cukup besar, hal ini dikarenakan jumlah variabel yang dimasukkan dalam penelitian hanya tiga variabel bebas.Dari tabel 4.24 Diperoleh persamaan jalur sebagai berikut:

\begin{tabular}{|c|c|c|c|c|c|}
\hline \multicolumn{6}{|c|}{ Coefficients $^{a}$} \\
\hline \multirow[b]{2}{*}{ Model } & \multicolumn{2}{|c|}{ Unstandardized Coefficients } & \multirow{2}{*}{$\begin{array}{c}\text { Standardized } \\
\text { Coefficients } \\
\text { Beta }\end{array}$} & \multirow[b]{2}{*}{$\mathrm{t}$} & \multirow[b]{2}{*}{ Sig. } \\
\hline & B & Std. Error & & & \\
\hline $1 \quad$ (Constant) & .142 & .080 & & 1.777 & .079 \\
\hline $\begin{array}{l}\text { Pengetahuan } \\
\text { Produk }\end{array}$ & .223 & .100 & .217 & 2.222 & .029 \\
\hline Label Halal & .178 & .088 & .199 & 2.036 & .045 \\
\hline Promosi & .200 & .086 & .198 & 2.334 & .022 \\
\hline Harga & .271 & .099 & 277 & 2.742 & .007 \\
\hline
\end{tabular}

$$
\mathrm{Z}=0.314 \mathrm{X}_{1}+0.257 \mathrm{X}_{2}+0.310 \mathrm{X}_{3}+0.721
$$

\section{Tabel 14 Pembentukan Jalur II}

a. Dependent Variable: Keputusan Pembelian

Sumber: Data primer yang diolah 2020

Berdasarkan tabel 14 dapat diketahui persamaan regresi sebagai berikut:

$$
\begin{aligned}
& Y=b_{1} X_{1}+b_{2} X_{2}+b_{3} X_{3}+b_{4} Z+e_{2} \\
& Y=0.217 X_{1}+0.199 X_{2}+0.198 X_{3}+0.277 Z+e_{2}
\end{aligned}
$$

Hasil output pada tabel 14 memberikan nilai Standardized beta pengetahuan produk sebesar 0.217 dengan nilai Sig. 0.029, label halal sebesar 0.199 dengan nilai Sig. 0.045, promosi sebesar 0.198 dengan nilai Sig. 0.022, dan harga sebesar 0.277 dengan nilai Sig. 0.007 dimana nilai Sig. lebih kecil dari 0.05 artinya variabel harga mampu memediasi. Harga akan menjadi pertimbangan konsumen dalam membuat keputusan pembelian karena harga merupakan unsur penting dalam penjualan yang akan membuat kesan baik atau buruk suatu produk sesuai dengan kegunaan dan manfaatnya. Namun nilai Sig. dalam variabel keputusan pembelian terjadi kenaikan pada koefisien variabel harga pada tabel 4.24, artinya variabel harga tidak memediasi variabel pengetahuan produk, label halal dan promosi terhadap keputusan pembelian secara sempurna. Hal ini memiliki arti meningkatnya pengetahuan produk, terdapat label halal pada produk dan promosi yang baik dan menarik, harga bukan menjadi salah satu pertimbangan responden dalam membuat keputusan pembelian produk kosmetik halal.

\section{Tabel 15 Nilai R square}

Model Summary ${ }^{b}$ 


\begin{tabular}{|l|c|r|r|r|}
\hline Model & R & R Square & Adjusted R Square & Std. Error of the Estimate \\
\hline 1 & .706 & .498 & .477 & .07191 \\
\hline
\end{tabular}

a. Predictors: (Constant), Harga , Promosi, Label Halal, Pengetahuan Produk

b. Dependent Variable: Keputusan Pembelian

Sumber: Data primer yang diolah 2020

Berdasarkan tabel 4.27 maka dapat diketahui bahwa nilai Adjusted $\mathrm{R}$ square sebesar 0.498 atau $49.8 \%$. hal tersebut menunjukkan bahwa variabel independen yaitu pengetahuan produk, label halal dan promosi mampu menjelaskan $49.8 \%$ dari variabel keputusan pembelian dimana sisanya $50.2 \%$ dijelaskan oleh faktor lain yang tidak diteliti dalam penelitian ini.

Berdasarkan tabel 4.27 nilai $\mathrm{e}_{1}$ sebesar:

$$
\begin{aligned}
& \mathrm{e}_{2}=\sqrt{1-R^{2}} \\
& \mathrm{e}_{2}=\sqrt{1-0.498} \\
& \mathrm{e}_{2}=0.706
\end{aligned}
$$

Perhitungan tersebut diketahui bahwa e 2 cukup besar yaitu 0.706.

Berdasarkan sub jalur I dan II didapat suatu model analisis jalur sebagai berikut:

Gambar 3Analisis Jalur

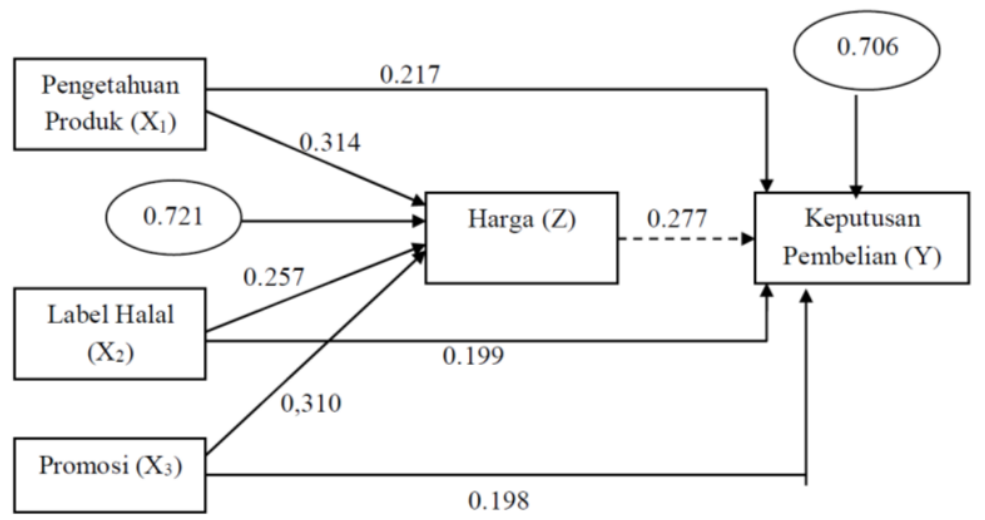

Besarnya pengaruh langsung dan tidak langsung dari masing-masing variabel, sebagai berikut:

a. Pengaruh langsung (direct effect) variabel pengetahuan produk $\left(\mathrm{X}_{1}\right)$, label halal $\left(\mathrm{X}_{2}\right)$ dan promosi $\left(\mathrm{X}_{3}\right)$ terhadap harga $(\mathrm{Z})$.

Rumus perhitungan pengaruh langsung adalah sebagai berikut.

$\mathrm{Z}=\mathrm{P} \mathrm{X}_{1} \mathrm{Y} \times \mathrm{P} \mathrm{X}_{1} \mathrm{Y}$

$Z=0.217 \times 0.217=0.047$

$\mathrm{Z}=\mathrm{P} \mathrm{X}_{2} \mathrm{Y} \times \mathrm{P} \mathrm{X}_{2} \mathrm{Y}$

$Z=0.199 \times 0.199=0.039$

$\mathrm{Z}=\mathrm{PX}_{3} \mathrm{Y} \times \mathrm{P} \mathrm{X}_{3} \mathrm{Y}$

$Z=0.198 \times 0.198=0.039$

b. Pengaruh tidak langsung (indirect effect) variabel pengetahuan produk $\left(\mathrm{X}_{1}\right)$, label halal $\left(\mathrm{X}_{2}\right)$ dan promosi $\left(\mathrm{X}_{3}\right)$ terhadap keputusan pembelian $(\mathrm{Y})$ melalui harga $(Z)$. 
1) Pengaruh tidak langsung (indirect effect) variabel pengetahuan produk $\left(X_{1}\right)$ terhadap keputusan pembelian $(Y)$ melalui harga $(Z)$.

$$
\begin{aligned}
& Z=P_{1} Z \times P Z Y \\
& Z=0.314 \times 0.277 \quad=0.086
\end{aligned}
$$

2) Pengaruh tidak langsung (indirect effect) variabel label halal $\left(X_{2}\right)$ terhadap keputusan pembelian (Y) melalui harga (Z).

$$
\begin{aligned}
& Z=P_{2} Z \times P Z Y \\
& Z=0.257 \times 0.277 \quad=0.071
\end{aligned}
$$

3) Pengaruh tidak langsung (indirect effect) variabel promosi $\left(X_{3}\right)$ terhadap keputusan pembelian (Y) melalui harga (Z).

$$
\begin{aligned}
& \mathrm{Z}=\mathrm{P} \mathrm{X}_{3} \mathrm{Z} \times \mathrm{P} \mathrm{Z} \mathrm{Y} \\
& Z=0.310 \times 0.277 \quad=0.085
\end{aligned}
$$

c. Pengaruh total variabel pengetahuan produk $\left(\mathrm{X}_{1}\right)$, label halal $\left(\mathrm{X}_{2}\right)$, promosi $\left(\mathrm{X}_{3}\right)$ dan harga $(\mathrm{Z})$ terhadap keputusan pembelian $(\mathrm{Y})$ dapat dihitung sebagai berikut:

1) Total variabel Pengetahuan Produk $\left(X_{1}\right)$

Pengaruh Total $=$ pengaruh tidak langsung + pengaruh langsung

Pengaruh total $\quad=0.047+0.086=0.133$

2) Total variabel label halal $\left(X_{2}\right)$

Pengaruh Total $=$ pengaruh tidak langsung + pengaruh langsung

Pengaruh total $\quad=0.039+0.071=0.11$

3) Total variabel promosi $\left(X_{3}\right)$

Pengaruh Total $=$ pengaruh tidak langsung + pengaruh langsung

Pengaruh total $\quad=0.039+0.085=0.124$

Hasil uji mediasi menunjukan bahwa pengetahuan produk terhadap keputusan pembelian produk kosmetik halal melalui harga lebih besar dibanding pengaruh label halal dan promosi terhadap keputusan pembelian produk kosmetik halal.

3. Uji Sobel Test

1. Harga memediasi pengetahuan produk terhadap keputusan pembelian

$\mathrm{H}_{4}$ : Pengetahuan produk berpengaruh signifikan terhadap keputusan pembelian produk kosmetik halal dengan harga sebagai variabel mediasi

$$
\begin{aligned}
& S \boldsymbol{a b}=\sqrt{\boldsymbol{b}^{2} \boldsymbol{S} \boldsymbol{a}^{2}+\boldsymbol{a}^{2} \boldsymbol{S} \boldsymbol{b}^{2}+\boldsymbol{S} \boldsymbol{a}^{2} \boldsymbol{S} \boldsymbol{b}^{2}} \\
& S a b=\sqrt{0.277^{2} \cdot 0.098^{2}+0.314^{2} \cdot 0.099^{2}+0.098^{2} \cdot 0.099^{2}} \\
& S a b=\sqrt{0.00073+0.00096+0.00009} \\
& S a b=\sqrt{0.00178} \\
& S a b=0.04219
\end{aligned}
$$

Untuk menguji signifikansi pengaruh tidak langsung, maka perlu menghitung nilai $t$ koefisien dengan rumus sebagai berikut:

$$
\begin{aligned}
& t=\frac{a b}{s a b} \\
& t=\frac{0.314 .0 .277}{0.04219}
\end{aligned}
$$


$\mathrm{t}=2.06157$

Nilai $\mathrm{t}$ hitung dibandingkan dengan $\mathrm{t}$ tabel, jika $\mathrm{t}$ hitung $>\mathrm{t}$ tabel maka terjadi pengaruh mediasi.Berdasarkan $t$ tabel diketahui nilai $t$ tabel untuk N 100 sebesar 1.98447. Karena t hitung lebih besar dari t tabel atau $2.06157>1,98447$, maka dapat disimpulkan bahwa harga merupakan variabel mediasi antara pengetahuan produk terhadap keputusan pembelian produk kosmetik halal.

2. Harga memediasi label halal terhadap keputusan pembelian

$\mathrm{H}_{5}$ : Label halal berpengaruh signifikan terhadap keputusan pembelian dengan harga sebagai variabel mediasi

$$
\begin{aligned}
& S \boldsymbol{a b}=\sqrt{\boldsymbol{b}^{2} \boldsymbol{S} \boldsymbol{a}^{2}+\boldsymbol{a}^{2} \boldsymbol{S} \boldsymbol{b}^{2}+S \boldsymbol{a}^{2} \boldsymbol{S} \boldsymbol{b}^{2}} \\
& S a b=\sqrt{0.277^{2} \cdot 0.087^{2}+0.257^{2} 0.099^{2}+0.087^{2} 0.099^{2}} \\
& S a b=\sqrt{0.00058+0.00065+0.00007} \\
& S a b=\sqrt{0.00130} \\
& \text { Sab }=0.03577
\end{aligned}
$$

Untuk menguji signifikansi pengaruh tidak langsung, maka perlu menghitung nilai $\mathrm{t}$ koefisien dengan rumus sebagai berikut:

$$
\begin{aligned}
& t=\frac{a b}{s a b} \\
& t=\frac{0.257 .0 .277}{0.03577} \\
& t=1.99018
\end{aligned}
$$

Nilai $\mathrm{t}$ hitung dibandingkan dengan $\mathrm{t}$ tabel, jika $\mathrm{t}$ hitung $>\mathrm{t}$ tabel maka terjadi pengaruh mediasi. Berdasarkan $t$ tabel diketahui nilai $t$ tabel untuk N 100 sebesar 1.98447. Karena t hitung lebih besar dari t tabel atau $1.99018>1,98447$, maka dapat disimpulkan bahwa harga merupakan variabel mediasi antara label halal terhadap keputusan pembelian produk kosmetik halal.

3. Harga memediasi promosi terhadap keputusan pembelian

$\mathrm{H}_{6}$ : Promosi berpengaruh signifikan terhadap keputusan pembelian dengan harga sebagai variabel mediasi

$$
\begin{aligned}
& S \boldsymbol{a b}=\sqrt{\boldsymbol{b}^{2} \boldsymbol{S} \boldsymbol{a}^{2}+\boldsymbol{a}^{2} \boldsymbol{S} \boldsymbol{b}^{2}+S \boldsymbol{a}^{2} \boldsymbol{S} \boldsymbol{b}^{2}} \\
& S a b=\sqrt{0.277^{2} .0 .082^{2}+0.310^{2} 0.099^{2}+0.082^{2} 0.099^{2}} \\
& S a b=\sqrt{0.00051+0.00094+0.00006} \\
& S a b=\sqrt{0.00151} \\
& \text { Sab }=0.03962
\end{aligned}
$$

Untuk menguji signifikansi pengaruh tidak langsung, maka perlu menghitung nilai $t$ koefisien dengan rumus sebagai berikut:

$$
\begin{aligned}
t & =\frac{a b}{s a b} \\
t & =\frac{0.310 .0 .277}{0.03962} \\
\mathrm{t} & =2.16733
\end{aligned}
$$


Nilai $\mathrm{t}$ hitung dibandingkan dengan $\mathrm{t}$ tabel, jika $\mathrm{t}$ hitung $>\mathrm{t}$ tabel maka terjadi pengaruh mediasi.Berdasarkan $t$ tabel diketahui nilai $t$ tabel untuk N 100 sebesar 1.98447. Karena $t$ hitung lebih besar dari $t$ tabel atau $2.16733>1,98447$, maka dapat disimpulkan bahwa harga merupakan variabel mediasi antara pengetahuan produk terhadap keputusan pembelian produk kosmetik halal.

\section{Analisis Koefisien Determinasi (Adjusted R ${ }^{2}$ ) Tabel 16Hasil Uji Koefisien Determinasi (Adjusted R2)}

\begin{tabular}{|l|r|r|r|c|}
\hline \multicolumn{6}{|c|}{ Model Summary $^{\mathbf{b}}$} \\
\hline Model & \multicolumn{1}{|c|}{$\mathrm{R}$} & R Square & $\begin{array}{c}\text { Adjusted R } \\
\text { Square }\end{array}$ & $\begin{array}{c}\text { Std. Error of the } \\
\text { Estimate }\end{array}$ \\
\hline 1 & $.706 \mathrm{a}$ & .498 & .477 & .07191 \\
\hline
\end{tabular}

a. Predictors: (Constant), Harga , Promosi, Label Halal, Pengetahuan

Produk

b. Dependent Variable: Keputusan Pembelian

Sumber: Data primer yang diolah 2020

Berdasarkan tabel 16 diatas dapat diketahui bahwa koefisien determinasi Adjusted $R$ Square memiliki nilai sebesar 0,477 atau $47,7 \%$, sehingga dapat dinyatakan bahwa kemampuan variabel independen (pengetahuan produk, label halal dan promosi) sebesar $47.7 \%$ dan sisanya $52.3 \%$ dijelaskan oleh variabel lain yang di luar penelitian ini.

\section{PEMBAHASAN}

1. Pengaruh Pengetahuan Produk $\left(\mathrm{X}_{1}\right)$ terhadap Keputusan Pembelian $(\mathrm{Y})$

Berdasarkan hasil pengujian hipotesis diketahui bahwa pengetahuan produk berpengaruh signifikansi terhadap keputusan pembelian dengan hasil nilai $t$ hitung pengetahuan produk sebesar 2.222 dengan nilai signifikansi 0.029 lebih kecil dari $0.05(0.029<0.05)$.

Hal ini juga menunjukkan bahwa mahasiswi memiliki pengetahuan yang tinggi pada produk kosmetik halal, hasil penelitian terlihat dari tiga item pernyataan yang digunakan sebagai alat ukur variabel pengetahuan produk. Mahasiswi menyadari pentingnya pengetahuan produk yang dibeli, tingginya pengetahuan akan menjadikan individu lebih hati-hati dalam pemilihan suatu produk kosmetik. Semakin baik pengetahuan mahasiswi dalam sebuah produk kosmetik halal yang aman digunakan ini ditawarkan maka akan semakin tinggi keputusan pembelian produk kosmetik halal, sebaliknya. Semakin rendah pengetahuan mahasiswi tentang produk kosmetik halal maka semakin menurun untuk melakukan keputusan pembelian produk kosmetik halal yang aman digunakan.

Hasil penelitian ini mendukung dengan penelitian terdahulu yang dilakukan oleh Trizki Lastyawati (2019), Ichsani Mutiara dkk (2018), Rani Nur Khasanah dkk (2014) yang menyatakan bahwa pengetahuan produk berpengaruh signifikan terhadap keputusan pembelian.

2. Pengaruh Label Halal $\left(\mathrm{X}_{2}\right)$ terhadap Keputusan Pembelian (Y) 
Berdasarkan hasil pengujian hipotesis diketahui bahwa label halal berpengaruh signifikansi terhadap keputusan pembelian dengan hasil nilai $t$ hitung label halal sebesar 2.036 dengan nilai signifikansi 0.045 lebih kecil dari $0.05(0.045<0.05)$.

Hal ini menunjukkan bahwa mahasiswi merasa aman dan tertarik dengan produk kosmetik halal.Hasil penelitian terlihat dari tiga item pernyataan yang digunakan sebagai alat ukur variabel label halal. Mahasiswi memperhatikan ada tidaknya label halal pada suatu produk kosmetik yang dibeli, artinya mahasiswi menyadari pentingnya kehalalan pada suatu produk yang akan digunakan. Produk kosmetik halal aman digunakan karena bahan yang digunakan aman dan tidak mengandung bahan-bahan yang di haramkan dalam Al-Quran dan Hadist seperti alkohol/khamr, bahan-bahan yang berasal dari organ manusia, darah dan kotoran. Mengingat bahwa masyoritas masyarakat beragama Islam maka produk yang sesuai dengan syariat Islam akan lebih dianjurkan, mahasiswi akan merasa bahwa produk kosmetik halal lebih aman digunakan daripada produk kosmetik yang belum jelas kehalalannya.

Hasil penelitian ini mendukung dengan penelitian terdahulu yang dilakukan oleh Desi Rimika Amanda Sari (2019), Putri Dewi Utami (2019) dan Eka Dewi Setia Tarigan (2016) yang menyatakan bahwa label halal berpengaruh signifikan terhadap keputusan pembelian.

3. Pengaruh Promosi $\left(X_{3}\right)$ terhadap Keputusan Pembelian $(Y)$

Berdasarkan hasil pengujian hipotesis diketahui bahwa promosi berpengaruh signifikansi terhadap keputusan pembelian dengan hasil nilai $\mathrm{t}$ hitung promosi sebesar 2.334 dengan nilai signifikansi 0.022 lebih kecil dari $0.05(0.022<0.05)$.

Hal ini juga menunjukkan bahwa mahasiswi merasa menarik akan promosi yang dilakukan dalam suatu produk kosmetik halal. Hasil penelitian terlihat dari lima item pernyataaan yang digunakan sebagai alat ukur variabel promosi.

Promosi adalah arus informasi atau persuasi satu arah yang dibuat untuk mengarahkan seseorang atau organisasi kepada tindakan yang menciptakan pertukaran dalam pemasaran.Semakin baik promosi yang dilakukan maka masyarakat cenderng untuk melakukan keputusan pembelian produk kosmetik halal akan menjadi tinggi dan sebaliknya. Semakin rendah promosi yang dilakukan maka akan semakin rendah untuk mahasiswi melakukan keputusan pembelian produk kosmetik halal.

Hasil penelitian ini mendukung dengan penelitian terdahulu yang dilakukan oleh Angkondya Safrilla Mahardika (2018), Nina Indriastuty dkk (2017), Dhita Ayu Rosanty (2016) yang menyatakan bahwa promosi berpengaruh signifikan terhadap keputusan pembelian.

4. Pengaruh Pengetahuan Produk $\left(\mathrm{X}_{1}\right)$ terhadap Keputusan Pembelian ( $Y$ ) dengan Harga $(Z)$ sebagai variabel mediasi

Berdasarkan koefisien pada variabel harga memiliki nilai signifikansi sebesar 0.001 dan nilai signifikansi pada variabel keputusan pembelian 
sebesar 0.029. Harga tidak memediasi pengetahuan produk terhadap keputusan pembelian secara sempurna karena mengalami peningkatan pada nilai signifikansi, artinya meningkatnya pengetahuan produk pada responden, harga bukan menjadi salah satu pertimbangan dalam keputusan pembelian produk kosmetik halal.Dalam hasil uji sobel diketahui bahwa pengetahuan produk berpengaruh signifikansi terhadap keputusan pembelian dengan harga sebagai variabel mediasi. Hasil nilai $t$ hitung pengaruh pengetahuan produk pada harga dalam uji sobel test lebih besar dari $\mathrm{t}$ tabel $(\mathrm{df}=98$ dan tingkat signifikan 0.05$)$ sebesar $2.06157>1.98477$. Harga merupakan variabel mediasi antara pengetahuan produk terhadap keputusan pembelian.

Hal ini juga menunjukkan bahwa mahasiswi merasa aman dan tertarik dengan produk kosmetik halal.Hasil penelitian terlihat dari tiga item pernyataan yang digunakan sebagai alat ukur variabel pengetahuan produk. Pengetahuan produk pada responden akan menjadikan responden memperhatikan harga dengan manfaat yang terkandung dalam suatu produk.

Apabila harga yang ditawarkan sesuai dengan kebutuhan mahasiswi maka semakin tinggi mahasiswi akan melakukan keputusan pembelian produk kosmetik, sebaliknya. Apabila harga yang ditawarkan tidak sesuai dengan kebutuhan mahasiswi maka semakin menurun untuk melakukan keputusan pembelian.

Hasil penelitian ini mendukung dengan penelitian terdahulu yang dilakukan oleh Adelina Nur Zalisa (2019), Ichsani Mutiara (2018) dan Sanny Hanjaya (2016) yang menyatakan bahwa pengetahuan produk berpengaruh signifikan terhadap keputusan pembelian.

5. Pengaruh Label Halal $\left(\mathrm{X}_{2}\right)$ terhadap Keputusan Pembelian $(\mathrm{Y})$ dengan Harga (Z) sebagai variabel mediasi

Berdasarkan koefisien pada variabel harga memiliki nilai signifikansi sebesar 0.008 dan nilai signifikansi pada variabel keputusan pembelian sebesar 0.045. Harga tidak memediasi label halal terhadap keputusan pembelian secara sempurna karena mengalami peningkatan pada nilai signifikansi, artinya dengan adanya label halal yang membuat kepercayaan manfaat, kualitas dan bahan terbaik dalam suatu produk kosmetik, harga tidak menjadi salah satu pertimbangan responden dalam keputusan pembelian. Hasil uji sobel diketahui bahwa label halal berpengaruh signifikansi terhadap keputusan pembelian dengan harga sebagai variabel mediasi. Hasil nilai t hitung pengaruh label halal pada harga dalam uji sobel test lebih besar dari $\mathrm{t}$ tabel $(\mathrm{df}=98$ dan tingkat signifikan 0.05$)$ sebesar sebesar $1.99018>1.98477$. Harga merupakan variabel mediasi antara label halal terhadap keputusan pembelian.

Hal ini menunjukkan bahwa mahasiswi merasa aman akan kualitas pada produk kosmetik halal. Hasil penelitian terlihat dari tiga item pernyataan yang digunakan sebagai alat ukur variabel label halal.Besarnya kepercayaan responden terhadap suatu produk kosmetik yang berlabel halal memberikan 
rasa aman karena produk kosmetik yang digunakan menggunakan bahanbahan yang terbaik.Dalam pemilihan suatu produk, konsumen yang memiliki pemahaman agama akan lebih selektif saat memutuskan membeli suatu produk dengan meneliti apakah dalam kemasan tersebut terdapat label halal. Sebelum melakukan pembelian, mahasiswi memperhatikan manfaat dan kualitas pada suatu produk kosmetik.

Hasil penelitian ini mendukung dengan penelitian terdahulu yang dilakukan oleh Hayet (2019), Elin Intan Anggraini dkk (2019) dan Karolina Widiastuti (2019) yang menyatakan bahwa label halal berpengaruh signifikan terhadap keputusan pembelian.

6. Pengaruh promosi $\left(\mathrm{X}_{3}\right)$ terhadap Keputusan Pembelian $(\mathrm{Y})$ dengan Harga $(\mathrm{Z})$ sebagai variabel mediasi

Berdasarkan koefisien pada variabel harga memiliki nilai signifikansi sebesar 0.000 dan nilai signifikansi pada variabel keputusan pembelian sebesar 0.022. Harga tidak memediasi promosi terhadap keputusan pembelian secara sempurna karena mengalami peningkatan pada nilai signifikansi, artinya promosi dengan mencantumkan harga yang dilakukan perusahaan atau pedagang, harga bukan menjadi salah satu pertimbangan dalam keputusan pembelian.Hasil uji sobel diketahui bahwa promosi berpengaruh signifikansi terhadap keputusan pembelian dengan harga sebagai variabel mediasi. Hasil nilai t hitung pengaruh promosi pada harga dalam uji sobel test lebih besar dari $\mathrm{t}$ tabel ( $\mathrm{df}=98$ dan tingkat signifikan 0.05 ) sebesar $2.16733>1.98477$. Harga merupakan variabel mediasi antara promosi terhadap keputusan pembelian.

Hal ini menunjukkan bahwa mahasiswi merasa manfaat dari produk kosmetik yang dibeli sesuai dengan harga yang ditawarkan.Hasil penelitian terlihat dari tiga item pernyataan yang digunakan sebagai alat ukur variabel promosi mayoritas.Dalam mempromosikan dagangan dapat menggunakan berbagai sarana baik lisan ataupun tertulis dan bisa menggunakan media sosial yang saat ini banyak digunakan oleh manusia. Perusahaan harus bisa memberikan promosi yang menarik agar konsumen tertarik dengan suatu produk tersebut.Semakin menarik promosi yang dilakukan dengan memberikan diskon, pada saat melakukan promosi memberikan harga yang sesuai dengan kualitas dan manfaat maka semakin tinggi mahasiswi untuk melakukan keputusan pembelian produk kosmetik halal.

Hasil penelitian ini mendukung dengan penelitian terdahulu yang dilakukan oleh Rifi Eriza (2019), Ummu Habibah (2016) dan Wahyu Erdalina dkk (2015) yang menyatakan bahwa promosi berpengaruh signifikan terhadap keputusan pembelian.

\section{KESIMPULAN}

Berdasarkan hasil analisis dan pembahasan yang telah diuraikan serta telah pengujian, maka dapat ditarik kesimpulan: 
1. Pengetahuan Produk, Label Halal dan Promosi secara parsial berpengaruh signifikan terhadap keputusan pembelian produk kosmetik halal.

2. Harga berpengaruh sebagai variabel mediasi antara Pengetahuan Produk, Label Halal dan Promosi terhadap Keputusan Pembelian. Produk Kosmetik Halal Variabel mediasi diuji dengan menggunakan uji sobel tes mendapatkan nilai $\mathrm{t}$ hitung pada Harga memediasi Pengetahuan Produk terhadap Keputusan Pembelian Produk Kosmetik Halal sebesar 2.06157 > 1.98447 ( t tabel $N=100$ ), nilai t hitung Harga memediasi Label Halal terhadap Keputusan Pembelian Produk Kosmetik Halal sebesar $1.99018>1.98447$ (t tabel $\mathrm{N}=100$ ), nilai $\mathrm{t}$ hitung pada Harga memediasi Promosi terhadap Keputusan Pembelian Produk Kosmetik Halal sebesar $2.16733>1.98447$ (t tabel $\mathrm{N}=100)$.

3. Berdasarkan pengujian dengan Adjusted $R$ square pada koefisien determinasi diketahui besarnya pengaruh variabel independen terhadap variabel dependen sebesar $47.7 \%$ dan sisanya $52.3 \%$ dijelaskan oleh variabel lain yang di luar penelitian ini. Misalnya pada penelitian terdahulu yaitu variabel kualitas produk dan gaya hidup.

\section{KETERBATASAN}

Penelitian ini memiliki beberapa keterbatasan antara lain:

1. Variabel independen yang digunakan dalam penelitian ini terbatas hanya pengetahuan produk, label halal, promosi dan harga.

2. Penelitian ini hanya dilakukan pada Fakultas Ekonomika dan Bisnis Universitas Muhammadiyah Pekajangan Pekalongan dengan jumlah responden sebanyak 100 orang sehingga belum dapat digeneralisasikan sebagai hasil penelitian yang mewakili seluruh mahasiswi Universitas Muhammadiyah Pekajangan Pekalongan.

3. Terdapat $52.3 \%$ variabel lain yang tidak dijelaskan dalam penelitian ini, sehingga perlu diperluas untuk cakupan penelitian terkait dengan faktorfaktor yang mempengaruhi keputusan membeli produk kosmetik halal pada penelitian mendatang.

\section{SARAN}

Berdasarkan hasil penelitian yang diperoleh, maka saran yang dapat diberikan sebagai berikut:

1. Objek Penelitian

Berdasarkan hasil penelitian, diketahui masih ada responden yang belum menyadari ada tidaknya label halal pada kemasan, memperhatikan dan memahami tentang produk kosmetik halal. Oleh karena itu, disarankan untuk meningkatkan pengetahuan mahasiswi tentang pentingnya kehalalan suatu produk yang digunakan tidak terkecuali kosmetik.

2. Penelitian Selanjutnya

Bagi penelitian selanjutnya yang ingin meneliti atau melanjutkan penelitian ini, disarankan dapat menambah objek penelitian sehingga jumlah responden lebih banyak sebagai bentuk pengambilan sampel dalam 
kuesioner dan menambah variabel lain karena masih banyak faktor yang mempengaruhi keputusan pembelian produk kosmetik halal.

\section{IMPLIKASI}

Berdasarkan pada hasil penelitian ini, maka diharapkan dapat bermanfaat dan sebagai pertimbangan dalam praktik yang berkaitan dengan pengetahuan produk, label halal, promosi dan harga terhadap keputusan pembelian produk kosmetik halal. Memperkuat pemahaman para peneliti tentang perilaku konsumen yang berkaitan dengan cara seseorang mengambil keputusan pembelian produk kosmetik halal.

Hasil penelitian ini digunakan sebagai masukan bagi responden untuk membenahi diri sehubungan dengan kehalalan suatu produk yang dianjurkan Al-Quran dan Hadist.

\section{DAFTAR PUSTAKA}

Adityangga, K. (2006). Membumikan Ekonomi Islam: Diskursus Pengembangan Ekonomi Berbasis Syariah. Yogyakarta: Pilar Media.

Alimin, M. (2004). Etika dan Perlindungan Konsumen dalam Ekonomi Islam. Yogyakarta: BPFE.

Burhanuddin. (2011). Pemikiran Hukum Perlindungan Konsumen E Setifikat Halal. Malang: UIN Maliki Press.

Drs. Basu Swastha Dh., M. d. (2003). Manajemen Pemasaran Modern. Yogyakarta: Liberty Offset.

Drs. Indriyono Gitosudarmo, M. (2008). Manajemen Pemasaran Edisi Kedua. Yogyakarta: BPFE.

Ghozali, I. (2005). Aplikasi Analisis Multivariate dengan Program SPSS. Semarang: Universitas Diponegoro.

Ghozali, I. (2009). Aplikasi Analisis Multivariative Dengan Program SPSS . Semarang: Universitas Diponegoro.

Ghozali, I. (2013). Aplikasi Analisis Multivariative Dengan Program SPSS Edisi 7. Semarang: Universitas Diponegoro.

Hasan, M. I. (2013). Pokok-Pokok Materi Statistik 1: Statistik Deskriptif. Jakarta: Bumi Aksara.

Hidayat, M. (2010). An Introduction to the Sharia ECONOMIC, Pengantar Ekonomi Syariah. Jakarta: Zikrul Hakim.

Keller, P. K. (2008). Manajemen Pemasaran Edisi Ketiga Belas. Jakarta: Erlangga.

Latifah, R. I. (2013). Buku Pegangan Ilmu Pengetahuan Kosmetik. Jakarta: Gramedia Pustaka Utama.

Oentoro, D. (2012). Manajemen Pemarasan Modern. Yogyakarta: LaksBang Pressindo.

Olson, P. J. (1999). Perilaku Konsumen dan Strategi Pemasaran Jilid Kedua. Jakarta: Erlangga.

Prof.DR.H. Rachmat Syafei, M. (2000). Fiqh Muamalah. Bandung: Pustaka Setia.

Qardhawi, Y. (1997). Norma dan Etika Ekonomi Syariah. Jakarta: Gema Insani. 
Qardhawi, Y. (2007). Halal dan Haram dalam Islam.Surakarta: Era Intermedia.

Stanton, W. J. (1996). Prinsip Pemasaran Edisi Ketujuh. Jakarta: Erlangga.

Sudaryono. (2016). Manajemen Pemasaran Teori dan Implementasi.Yogyakarta: Andi Offset.

Sudaryono, D. (2016). Manajemen Pemasaran Teori dan Implementasi. Yogyakarta: Andi.

Sugiono. (2012). Metode Penelitian Kuantitatif Kualitatif. Bandung: Alfabeta.

Sugiyono. (2001). Metode Penelitian Administrasi. Bandung: Alfabeta.

Sumarwan, U. (2002). Perilaku Konsumen: Teori dan Penerapannya dalam Pemasaran. Bogor: Ghalia Indonesia.

Sumarwan, U. (2011). Perilaku Konsumen. Bogor: Ghalia Indonesia.

Bahri, Syabbul. 2013. Hukum Promosi Produk Dalam Perspektif Hukum Islam.Jurnal.Institut Agama Islam Negeri. Surabaya

Damara, Aria. 2019. Analisis Viktimologis Terhadap Kejahatan Perdagangan Kosmetik Ilegal Berbahaya Di Kota Bandar Lampung.Skripsi. Unversitas Lampung. Bandar Lampung

Hayet.2019. Pengaruh Labelisasi Halal Terhadap Keputusan Pembelian Produk Kosmetik (Studi Kasus Di Kota Pontianak, Kalimantan Barat, Indonesia).Jurnal. Universitas Tanjungpura. Pontianak

Indraswari, Retno dkk.2018. Analisis Faktor-Faktor Pengambilan Keputusan Pembelian Kosmetik Berlabel Halal Di Kota Bogor.Jurnal. Institute Pertanian Bogor. Bogor

Khasanah, Rani Nur dkk.2014. Pengaruh Kemasan, Label Halal, Dan Pengetahuan Produk Terhadap Keputusan Pembelian (Studi Pada Kpnsumen Kosmetik Wardah Di Kota Palembang).Jurnal Ilmiah Manajemen Bisnis Dan Terapan. Palembang

Rahayu, Tuti Sri dkk. 2018. Pengaruh Labelisasi Halal, Harga, Promoso Penjualan

Dan Brand Imgae Terhadap Keputusan Pembelian Konsumen Pada Produk Kosmetik Halal (Studi Kasus Mahasiswi Prodi Manajemen Angkatan 20142016 Fakultas Ekonomi Universitas Maritime Raja Ali Haji). Jurnal. Universitas Maritim Raja Ali Haji. Tanjung Pinang

Rahayu, Rovi Tri. 2019. Pengaruh Kualitas Produk Dan Kualitas Pelayanan Terhadap Minat Beli Produk Kosmetik Online Pada Mahsiswa Jurusan Perbankan Syariah FEBI Institut Agama Islam Negeri Ponorogo. Skripsi. Ponorogo

Rahmawati, Vivi. 2014. Pengaruh Atribut Produk Dan Label Halal Sebagai Variabel Moderating Terhadap Keputusan Pembelian Produk Kosmetik Wardah Di Kota Semarang.Jurnal. Universitas Dian Nuswantoro. Semarang

Sadzalia, Shovi. 2015. Pengaruh Label Halal Dan Religiusitas Terhadap Keputusan Pembelian Produk Kosmetik Di Kota Malang.Skripsi.Universitas Islam Negeri Maulana Malik Ibrahim. Malang

Sari, Desi.2019. Pengaruh Label Halal, Harga Dan Citra Merek Terhadap Keputusan Pembelian Produk Kosmetik Wardah Pada Mahasiswi Fakultas Ekonomi Dan Bisnis Islam IAIN Tulungagung.Jurnal.Institut Agama Negeri Islam. Tulungagung 
Trihandono, Novie Agung. 2020. Pengaruh Kualitas Produk, Persepsi Harga Dan Promosi Terhadap Keputusan Pembelian Kosmetik Herborist (Studi Empiris Pada Konsumen PT. Victoria Care Indonesia Semarang). Skripsi. Universitas Stikubank. Semarang

Sari, Tina Kurinia. 2018. Analisis Pengaruh Kualitas Produk dan Cira Mere Terhadap Keputusan Pembelian Konsumen Melalui Harga Sebagai Variabel Intervening (Studi Pada Konsumen Pelembab Wajah Olay di Semarang). Skripsi. Unissula. Semarang

https:/ / kemenperin.go.id/artikel/18957/Industri-Kosmetik-NasionalTumbuh, diakses pada tanggal 19 November 2019 pukul 18.38 WIB https:/ / lifestyle.bisnis.com/read/20190812/104/1135606/ini-penyebabkosmetik-indonesia-mulai-bersinar, diakses pada tanggal 3 Juni 2020 pukul 19.40 WIB

https:/ / kupang.tribunnews.com/2020/01/03/daftar-113-kosmetik-cewekdilarang-bpom-karena-berbahaya-dari-krim-syahrini-hingga-skin-carekorea?page $=3$, diakses pada tanggal 11 Juni 2020 pukul 21.48 WIB

https:/ / radarmojokerto.jawapos.com/read/2019/01/16/113970/bbpombanyak-konsumen-online-jadi-korban-kosmetik-ilegal, diakses pada tanggal 18 Juni 2020 pukul 18.32 WIB

https://www.cnnindonesia.com/ekonomi/20191016145608-92-440050/mulaibesok-semua-produk-wajib-bersertifikat-halal, diakses pada tanggal 18 Oktober 2019 pukul 19.18 WIB

https:/ / lokadata.id/artikel/waspada-terhadap-edaran-kosmetik-palsu, diakses pada tanggal 18 Juni 2020 pukul 19.04 WIB 